\title{
Gender Difference in Job Satisfaction and Its Relation to Subjective Sense of Well-Being and Level of Happiness in Medical Doctors of West Bengal
}

\author{
Priyankar Singha ${ }^{1 *}$, Dr. Souvik Raychaudhuri ${ }^{2}$
}

\section{ABSTRACT}

The present study deals with gender difference in job satisfaction among the doctors of west bengal. Attempts were also made to assess their subjective sense of well being and the level of happiness. The sample size was 110 divided into 2 groups (male- 67 and female- 43). Each group was consisted respondents age ranging between 22-35 years and having minimum 2 years of job experience. The data were collected from several public sector hospitals of west bengal. Job satisfaction scale, Subjective well being inventory and Oxford happiness inventory were administered to assess the level of job satisfaction, subjective sense of well being and level of happiness. It is revealed that female doctors were found to be more satisfied than male doctors in their job and in case of subjective sense of well being and level of happiness the same result has been found. A significant difference between the gender has been revealed in subjective sense of well being, level of happiness and level of job satisfaction as well. Furthermore, significant correlation has been found between job satisfaction and level of happiness for the entire group of selected sample and a significant correlation could not be drawn between job satisfaction and subjective sense of well being for the present sample. The results of the present study can be fruitful for further research studies.

Keywords: Job Satisfaction, Gender Difference, Well Being, Happiness.

The concept of job satisfaction has been developed in many ways by many different researchers and practitioners. One of the most widely used definitions in organizational research is that of Locke (1976), who defines job satisfaction as "a pleasurable or positive emotional state resulting from the appraisal of one's job or job experiences" Locke, E. A. (1976). Others have defined it as simply how content an individual is with his or her job; whether he or she likes the job or not

\footnotetext{
${ }^{1}$ Ph.D research scholar, Department of psychology, Calcutta university, Kolkata, India

${ }^{2}$ Associate professor, Department of Psychology, Calcutta University, Kolkata, India

*Responding Author

(C) 2016 I P Singha, S Raychaudhuri; licensee IJIP. This is an Open Access Research distributed under the terms of the Creative Commons Attribution License (http://creativecommons.org/licenses/by/2.0), which permits unrestricted use, distribution, and reproduction in any Medium, provided the original work is properly cited.
} 


\section{Gender Difference in Job Satisfaction and Its Relation to Subjective Sense of Well-Being and Level of Happiness in Medical Doctors of West Bengal}

(Spector, P.E. (1997). It is assessed at both the global level (whether or not the individual is satisfied with the job overall), or at the facet level (whether or not the individual is satisfied with different aspects of the job). Spector (1997) lists 14 common facets: Appreciation, Communication, Co-workers, Fringe benefits, Job conditions, Nature of the work, Organization, Personal growth, Policies and procedures, Promotion opportunities, Recognition, Security, and Supervision).

Job satisfaction is an important element of employee's behaviour which affects not only the individual's behaviour but also benefited the goal of organization. Actually satisfied employees are more committed to their work. Job satisfaction comes from the variety of ways. Some employees satisfied with their pay structure or compensation, some are with nature of job, promotion, supervision, colleagues, benefits etc. A satisfied employee is free from work stress and they become more productive.

Job satisfaction becomes a major concern for most of the organization. Good organization tries to find out the different approaches regarding employee's satisfaction. Management periodically review responses of their employees on the various function of HR and organizational policy and suggest innovative measures for their satisfaction.

Getting satisfaction from the job it not only concern or effort of management. Individual employee is also responsible for job satisfaction, if, he become more self-aware and learns self aptitudes, ability, values, preferences and interests and be prepared to expressive where they can best contribute and what is important to them.

Several research being studied in the field of Job Satisfaction, show that there are gender differences in job satisfaction. It has been studied that though women's role at work are lesser in position and pay, they have lesser complains of dissatisfaction at work. Job Satisfaction depends on the job characteristics, family responsibility and personal expectation of the employees (Flarencis et.al , 2010). A lot of studies state that women face greater work load stress leading to a lower overall satisfaction compared to men. There is a significant gender difference seen in time management, organisational support, job pressures and pay and increment (Hodson Randy, 1989). The employees' personality and attitude towards women and their growth in the company matter a lot in experiencing a higher job satisfaction as it will not make a difference in one's job satisfaction if being supervised by a woman (Belsky et.al, 1985).

There has been a recent interest in exploring factors influencing job satisfaction with a specific focus on gender differences. Clark (1997) used a large-scale survey to test the proposition that men and women in identical jobs should be equally satisfied. Study results reported that the average job for females was lower in stature and income than for males, yet females reported 


\section{Gender Difference in Job Satisfaction and Its Relation to Subjective Sense of Well-Being and Level of Happiness in Medical Doctors of West Bengal}

higher levels of job satisfaction. Sousa-Poza and Souza-Poza (2003) report similar findings from a national household panel survey in the Britain. In a study among women working in the private banking sector, Metle (2001) found that job satisfaction declines with increasing levels of education. Metle (2001) argues that higher levels of education tend to increase employee goal and income expectations. Women participating in the study reported gender discrimination in seniority and qualifications.

Men and women working in gender-balanced groups have higher levels of job satisfaction than those who work in homogeneous groups. Employees who work in groups comprised of mostly men tend to show the lowest levels of job satisfaction, and those working in groups of mostly women fall in the middle of the gender-balanced and mostly-men groups (Fields \& Blum, 1997).

Pook, Füstös, and Marian (2003) surveyed 932 employees in Eastern Europe to explore the impact of gender bias on job satisfaction. Results suggest that women are less likely to receive help from their managers toward advancement and are less satisfied than men with the work they performed. This may be the result of being assigned less-challenging tasks, non-commensurate with their backgrounds.

Using data from the U.S. National Study of the Changing Workforce, Bender, Donohue, and Heywood (2005) report that overall women have higher job satisfaction than men and have higher job satisfaction in workplaces dominated by women. However, men and women value job flexibility differently, and once this difference is controlled for, gender composition in the workplace plays no role in determining job satisfaction of women.

Gender difference in Job satisfaction is a major concern for organisations in today's global workforce and has been widely studied throughout Organisational Psychological and Managerial literature. The main purpose of the study is to explore the gender difference in job satisfaction among the medical doctors of West Bengal, India and its relations to their sense of well being and level of happiness.

\section{RESEARCH METHODS}

\section{Hypothesis:}

1. There is a significant difference between the male and female medical doctors regarding Job satisfaction, subjective sense of well being and level of happiness.

2. There will be a significant relationship between the variables (namely, job satisfaction and subjective sense of well being; job satisfaction and level of happiness) of male and female medical doctors.

(C) The International Journal of Indian Psychology, ISSN 2348-5396 (e)| ISSN: 2349-3429 (p) | 178 


\section{Gender Difference in Job Satisfaction and Its Relation to Subjective Sense of Well-Being and Level of Happiness in Medical Doctors of West Bengal}

\section{Research design:}

This existing study is descriptive in its nature. Well, descriptive research can be defined as describing some particular situation, some phenomena or something. Descriptive researches are those which define the current situation instead of inferring and making judgments (Creswell, 1994). The core goal of the descriptive research is to verify the developed hypotheses that reveal the current situation. This kind of research offers information about current scenario and emphasis on the elements that effect the job satisfaction. Furthermore, the current research is comparative in nature, evaluating the Gender differences in Job Satisfaction experienced by male and female medical doctors.

\section{Sample and data:}

In order to gather data for understanding job satisfaction, a sample of 110 respondents was asked to take part in a self-administered questionnaire. The respondents for the current study was medical doctors of West Bengal. The total size of the sample was 110 and divide into two groups of gender (male- 67, female-43). The present research uses a non-probability sampling technique that is convenience sampling. Convenience sampling is a procedure that gains and gathers the appropriate information from the unit of study or sample that are suitably accessible (Zikmund, 1997).

\section{Data collection tools and measure:}

a) Job satisfaction was measured using job satisfaction scale by B.C. Muthayya (1973). The scale consisted of 34 items. The answer categories for each of the items were agree(A), not sure (NS), disagree(D) and not applicable(NA). The split-half reliability coefficient of the scale is 0.81 . The score range is $0-68$.

b) Level of happiness was measured using oxford happiness inventory (1980s). This inventory consisted of 29 items and each item having four incremental levels of response, numbered from 0 to 3 . The items receive the score same as the response given by the subjects, for e.g., response of 1 gets a score of 1 . The higher score denotes the higher level of happiness. The score ranges between $0-57$. The alpha reliability for the test is found to be 0.92 .

c) Sense of well being was measured by applying subjective well being inventory (Dupey,1970). The scale consisted of 40 items and can be scored by attributing the values 3, 2 and 1 to response categories of positive items and 1, 2 and 3to the response categories of negative items. The minimum and maximum scores that can be obtained are 40 and 120 . The test retest reliability for one month is found to be 0.91 .

\section{Statistical tool:}

Descriptive statistics and correlation statistics were done using spss (version 16.0). 
Gender Difference in Job Satisfaction and Its Relation to Subjective Sense of Well-Being and Level of Happiness in Medical Doctors of West Bengal

\section{TABLES AND RESULT}

Table-1showing the difference in mean, standard deviation and ' $t$ ' values between the male and female medical doctors of west bengal. ( $n=110$, male $=67$, female $=43)$.

\begin{tabular}{|c|c|c|c|c|c|c|}
\hline \multirow{2}{*}{ variables } & \multicolumn{2}{|c|}{ male } & \multicolumn{2}{c|}{ female } & \multirow{2}{*}{ 't' values } & $\begin{array}{c}\text { Level of } \\
\text { significance }\end{array}$ \\
\cline { 2 - 6 } & mean & $\begin{array}{c}\text { Standard } \\
\text { deviation }\end{array}$ & mean & $\begin{array}{c}\text { Standard } \\
\text { deviation }\end{array}$ & & \\
\hline Job satisfaction & 28 & 5.93 & 34.04 & 5.22 & 3.651 & $.001^{* *}$ \\
\hline happiness & 70.76 & 10.05 & 76.92 & 10.30 & 2.139 & $.038^{*}$ \\
\hline Sense of well being & 47.60 & 3.80 & 51.64 & 5.64 & 2.968 & $.005^{* *}$ \\
\hline
\end{tabular}

$* * \mathrm{p}<0.01, * \mathrm{p}<0.05$

Table- 2 Showing the product moment correlation coefficient values for the total group of male and female medical doctors of west bengal for level of happiness and sense of well being with the level of job satisfaction $(n=110)$.

\begin{tabular}{|c|c|}
\hline variables & Correlation coefficient \\
\hline Job satisfaction - level of happiness & $.215^{* *}$ \\
\hline Job satisfaction - sense of well being & .047 \\
\hline
\end{tabular}

$* * \mathrm{p}<0.01, * \mathrm{p}<0.05$

\section{DISCUSSION}

The study focuses on the job satisfaction of medical doctors of West Bengal and it's relationship to their subjective sense of well being and level of happiness. The finding has been discussed in the light of the comparison between the male doctors and female doctors.

It has been found that there is a significant difference between the means of the two groups with respect to level of job satisfaction, subjective sense of well being and the level of happiness. On the basis of result we can say that female doctors are more satisfied with their jobs as compared to male doctors as the mean of the female employees found to be greater than that of the male employees and the similar result has revealed in case of level of happiness and subjective sense of well being. These kind of result may be due to gender equality prevails, gender-balanced management, work/life balance, family-friendly values and practices and maternity leave provided by the government. Gender differences In today's world, women are taking a more active role in their careers. There are women who lead large companies, own their own businesses, and are very active in their community and work as well.

(C) The International Journal of Indian Psychology, ISSN 2348-5396 (e)| ISSN: 2349-3429 (p) | 180 


\section{Gender Difference in Job Satisfaction and Its Relation to Subjective Sense of Well-Being and Level of Happiness in Medical Doctors of West Bengal}

Happiness play a major role in the job satisfaction and it is a correlated factor to job satisfaction. If the employees are not happy in their personal life then they are not willing to be satisfied to their job. Dissatisfaction in work means they are not satisfied and in fact observations made here, reveal that employees appear to be satisfied as they are happy in their personal life.

The correlation between job satisfaction and subjective sense of well being has not been found to be significant. So it can be interpreted that the level of job satisfaction and the quality in subjective sense of well being are not associated with each other for the selected sample of the present study.

The findings reveal some, interesting trends regarding different facets of the doctors of West Bengal (male and female). The inter-group comparison between the male and female doctors have indicated significant difference with respect to measure of selected variables. However, the relationship between the variables has generated some interesting findings which throw some light upon the issue of job satisfaction among the employees of medical sector.

\section{LIMITATION OF THE STUDY}

1. Respondent's opinions are dynamic; they keep changing from time to time.

2. Some of the respondents might not have given the actual information due to fear of being disclosed.

3. The results are confined to only few of hospitals of west bengal and cannot be generalized for other state of India.

4. The study was conducted with the limited number of respondent due to time constraint.

5. Study may be obsolete because of changing environment and needs.

6. Satisfaction level to various factors may differ from person to person.

7. Medical doctors of private organization was not included in the present study.

\section{SUGGESTION FOR THE FURTHER STUDY}

This model also can be applied to more no of respondents including the other public and private sector medical organization of overall the country for measuring the gender difference in job satisfaction.

\section{CONCLISION}

There does exist a significant difference between male and female medical doctors in accordance to level of job satisfaction, level of happiness and subjective sense of well being and furthermore female doctors are found to be more satisfied in their job than the male doctors of west bengal. Job satisfaction and level of happiness are significantly correlated with each other among the doctors of west Bengal.

(C) The International Journal of Indian Psychology, ISSN 2348-5396 (e) | ISSN: 2349-3429 (p) | 181 


\section{Gender Difference in Job Satisfaction and Its Relation to Subjective Sense of Well-Being and Level of Happiness in Medical Doctors of West Bengal}

\section{Acknowledgments}

The author appreciates all those who participated in the study and helped to facilitate the research process.

\section{Conflict of Interests}

The author declared no conflict of interests.

\section{REFFERENCES}

Bender, K. A., Donohue, S. M., \& Heywood, J. S. (2005). Job satisfaction and gender segregation. Oxford Economic Papers, 57, 479-496.

Clark, A. E. (1997). Job satisfaction and gender: Why are women so happy at work? Labour Economics, 4(4): 341-372.

Creswell, J. W. (1994). Research designs: Qualitative and quantitative approaches. Thousand Oaks, CA: Sage.

Fields, D., \& Blum, T. C. (1997). Employee satisfaction in work groups with different gender composition. Journal of Organizational Behavior, 18, 181-196.

Flarencis LB, Lucia Madrigal and cermen pages (2010), 'part time work, gender and job satisfaction', journal of development studies 46(9): 1543-71

Hodson Randy (1989), 'Gender Differences in Job Satisfaction: Why Aren't Women More Dissatisfied?’, The Sociological Quarterly, 30:3:385-99.

J Belsky, M Perry-Jenkin., \&Crouter (1985). The work-family interface and marital change across the transition to parenthood. Journal of Family Issues, 6, 205-20.

Locke,E.A. (1976). The nature and causes of job satisfaction. In M.D. Dunnette (Ed.), Handbook of industrial and organizational psychology (pp.1297-1349). Chicago: Rand McNally.

Metle, M. K. (2001). Education, job satisfaction and gender in Kuwait. International Journal of Human Resource Management, 12: 311-332.

Pook, L. A., Füstös, J., \& Marian, L. (2003). The impact of gender bias on job satisfaction Components of job satisfaction and advancement in post-liberation Hungary, Poland, and Romania. Human Systems Management, 22(1): 37-50.

Sousa-Poza, A., \& Sousa-Poza, A. A. (2003). Gender differences in job satisfaction in Great Britain, 1991-2000: Permanent or transitory? Applied Economics Letters, 10(11): 691-694.

Spector, P.E. (1997). Job satisfaction: Application, assessment, causes and consequences. Thousand Oaks, CA: SAGE.

Zikmund, W.R., (1997), Business Research Methods(5th Ed.), the Dryden Press, Fort Worth, Texas.

How to cite this article: P Singha, S Raychaudhuri (2016), Gender Difference in Job Satisfaction and Its Relation to Subjective Sense of Well-Being and Level of Happiness in Medical Doctors of West Bengal, International Journal of Indian Psychology, Volume 3, Issue 4, No. 56, ISSN 2348-5396 (e), ISSN: 2349-3429 (p), DIP: 18.01.018/20160304, ISBN: 978-1-36523992-2 